\title{
The Influence of Financial Knowledge, Financial Attitude, and Financial Behavior on Professional Millennial's Financial Investment Choice
}

\author{
$1^{\text {st }}$ Reza F Pradana \\ Faculty of Administrative Sciences \\ Universitas Indonesia \\ Jakarta, Indonesia \\ reza.frendy81@ui.ac.ic
}

\author{
$2^{\text {nd }}$ Ferdinand D Saragih \\ Faculty of Administrative Sciences \\ Universitas Indonesia \\ Jakarta, Indonesia
}

\author{
$3^{\text {rd }}$ Bernadus Y Nugroho \\ Faculty of Administrative Sciences \\ Universitas Indonesia \\ Jakarta, Indonesia
}

\begin{abstract}
This research aims to examine the influence of financial knowledge, financial attitude, and financial behavior of professional Millennials on the choice of financial investment instruments (especially in deposits, stocks, mutual funds, golds, and bonds). This research uses questionnaires as a research instrument and takes 214 millennials who work in the professional sector as samples. The data is processed by using descriptive statistical analysis and Contingency Analysis to figure out the Chi-Square which will be compared to the Chi-Square Distribution Table. The results of this study indicate that financial knowledge, financial attitude, and behavior significantly influences the investment choice of Millennials.
\end{abstract}

Keyword-Financial Literacy, Financial Knowledge, Financial Attitude, Financial Behavior, Risk-return, Investment Choice, Millennials

\section{INTRODUCTION}

\begin{tabular}{|c|l|l|}
\multicolumn{4}{|c|}{ TABLE 1. CONTRIBUTION OF FINANCIAL INDUSTRY IN INDONESIA } \\
\hline Description & 2013 (IDR) & 2016 (IDR) \\
\hline Distribution of bank credit & 3.585 Trillion & 4.705 Trillion \\
\hline Stock market capitalization & 4.219 Trillion & 5.753 Trillion \\
\hline Gross insurance premium & 193 Trillion & 213 Trillion \\
\hline Receivables of financing & 348 Trillion & 387 Trillion \\
Pension fund investment & 157 Trillion & 229 Trillion \\
\hline
\end{tabular}

From the table above, it is known that bank lending is the activity that provided the highest contribution of IDR4,709.5 trillion in 2016. Furthermore, another significant role was also given due to the stock market capitalization, insurance premiums, financing, and investment in pension funds. Based on these data and research conducted by OJK [1], it can be concluded that Indonesian people have begun to have an awareness of investment for their post-productive period.

Halim explained that investment can be defined as the putting of a number of funds carried out in the present by expecting margin/profit in the future. In addition, investment can also be defined as an effort to delay
The financial services industry in Indonesia regionally takes part in giving contribution to the economic and financial sectors growth. This contribution is critical in supporting welfare of the community and economic development. This has only been realized through granting access to funding through the provision of bank credit. Thus, public can find it easier to get funding for their own businesses and/or needs [1]. Moreover, according to data released by the Central Statistics Agency/BPS [2], financial service institutions also have contributed to the increase in GDP through their role of financial intermediation. However, the magnitude of the provided financial services intermediation is still not optimal. By viewing the financial industry's share of GDP, they only contributed $3 \%$ of the total GDP. The contributions made by the financial services industry are reflected as in Table I below:

consumption (which can actually be done) in the hope of obtaining a benefit in the form of return for the time and risk of the investment. However, a person has the right to choose their investment instrument, such as investment presented by the banking sector, which includes savings, deposits and mutual funds, etc [3].

Millennial generation is a generation that is identified with confident, independent, and goal-oriented attitudes. Millennial generation is born when technology and the development of the digital world are in a massive condition. Hence, Millennials naturally know more about the development of these technologies compared to their previous generations [4]. These conditions make 
Millennials want personalized solutions that meet their individual needs. Their profile status correlates strongly with the type of goals they have and the challenges they face. They expect their financial institutions to be able to assist in overcoming financial goals, provide access to appropriate products, and provide professional advice and planning [5].

Furthermore, Millennials are thoughtful investors in making decisions. That is because they do not want to experience the same thing as what their parents suffered or other events that occurred in the vicinity. For this reason, they do different approach and research from those of the previous generation before investing in the money they have. The research they are doing is utilizing social media, websites, online simulation calculators, mobile applications and various platforms that are considered to be able to help them to get information regarding the best investment they believe in [6].

Putri in her research explained that the preferences of each individual are different from one to another. This is affected by differences in behavior and expectations for the investments they choose. In addition, there are differences in the level of risk and the level of return, which then affect the individual in making consideration of the selection of investment instruments [7].

Furthermore, financial behavior is relevant to the way a person treats, manages, and uses their financial resources. Individuals who have responsible financial behavior tend to be effective in using money, such as making money, managing expenses, investing, and paying consumption costs on time [8]. Based on a survey conducted by OJK, it is known that there are conditions that indicate the lack of public knowledge of products and services in relation to alternative financial investments that can be utilized. The public financial knowledge index of alternative financial investment instruments has the potential to be followed by the low level of financial inclusion of financial investment products and services that will be faced by the Indonesian people [1].

\section{THEORETICAL FRAMEWORK}

This study refers to several theories that serve as a reference which includes theories about financial literacy, financial knowledge, financial attitudes, financial behavior, investment, and millennial generation.

A. Financial Literacy

Financial literacy is the ability possessed by an individual in processing economic information related to financial planning, accumulation of wealth, debt, and oldage which can be used as a basis for making decisions in financial aspects [9]. Furthermore, Remund believes that financial literacy is a measurement of an individual's understanding of financial management concepts and capabilities (both short and long term) by considering various aspects. Moreover, several experts also support that the financial literacy possessed by an individual can develop their financial skills when they have been able to apply financial knowledge. Thus, these individuals might be able to make rational and effective financial decisions.

\section{B. Financial Knowledge}

Financial knowledge refers to aspects of personal financial management that can be measured at a level through financial concepts [13]. Likewise, the Organization for Economic Co-operation and Development/OECD explains that an individual can be categorized as having a good financial knowledge when the individual has a basic understanding related to financial concepts and the ability to apply numeracy skills [14]. Furthermore, Gannan (1985) as quoted by [15] found that an individual who has financial knowledge needs to develop financial capabilities by being able to utilize financial tools, i.e. credit cards, debit cards, investment instruments, or other financial tools.

\section{Financial Attitude}

Parrotta and Johnson (1998) in [15] explain that financial attitudes can be considered as a psychological tendency that is trying to be expressed when evaluating the recommended financial management practices by looking at some level of agreement or disagreement. Primarily, financial attitude was formed through beliefs related to economic and/or non-economic aspects believed by the individual. In this case, information can influence the mindset, and attitude can affect the financial decision making process [16]. Besides that, Furham reflects financial attitude into six concepts, namely Obsession, Power, Effort, Inadequacy, Retention, and Security [17].

\section{Financial Behavior}

Good financial behavior can be indicated by diversifying assets in various types of investments, due to each type of investment has its own specific risk profile. In addition, they also believe that financial behavior can also be shaped by socio-economic factors. Moreover, the level of financial knowledge and habits in financial management will also influence the formation of financial behavior. The higher the financial knowledge and financial behavior, the higher the tendency for getting more income, more assets, and higher education [18].

Thus, the above literature leads us to formulate the following research hypotheses:

- $\mathrm{Ha}_{1}$ : Financial Knowledge influences professional millennial investment choices

- $\mathrm{Ha}_{2}$ : Financial Attitude influences professional millennial investment choices

- $\mathrm{Ha}_{3}$ : Financial Behavior influences professional millennial investment choices

\section{RESEARCH METHOD}

This research aimed to measure the influence of financial knowledge, financial attitude, and financial behavior on investment choices for Millennials professional by carried out quantitative (positivism) approach. Furthermore, in terms of its objectives, this research can be categorized as explanatory research. The data was obtained through an online questionnaire to 214 respondents and used Likert-scale on range 1-5. After that, the data was analyzed with Contingency Analysis technique to determine the Chi-Square value. 


\section{RESULT}

\section{A. Respondents' Demography and Professional} Background

From the conducted survey, there are several aspects that can be described, including the gender of respondents, professional backgrounds, selected investment choice, and their level of financial knowledge, attitude, and behavior. From the demography and professional background perspectives, it is known that the respondents' gender, year of birth, and professional field are as mentioned on the table below:

\begin{tabular}{|l|c|c|c|}
\multicolumn{2}{c}{ TABLE II. DEMOGRAPHIC PROFILE OF RESPONDENTS } \\
\hline \multicolumn{1}{|c|}{ Kategori } & $\begin{array}{c}\text { Jumlah } \\
\text { (Responden) }\end{array}$ & $\begin{array}{c}\text { Jumlah } \\
(\%)\end{array}$ \\
\hline Gender & - Male & 163 & $76,2 \%$ \\
& - & 51 & $23,8 \%$ \\
\hline Year of Born & $-1986-1989$ & 35 & $16 \%$ \\
& $-1990-1994$ & 167 & $78 \%$ \\
& $-1995-1998$ & 12 & $6 \%$ \\
\hline Professional & - Tax Consultant & 68 & $32 \%$ \\
Backround & - Public Accountant & 46 & $21 \%$ \\
& - Doctor & 14 & $7 \%$ \\
& - Notary & 11 & $5 \%$ \\
& - Architech & 13 & $6 \%$ \\
& - Actuary & 17 & $8 \%$ \\
& - Management Consultant & 27 & $13 \%$ \\
& - Advocat & 11 & $5 \%$ \\
& - HR Consultant & \\
\hline
\end{tabular}

According to the demographic profile, it shows that 163 respondents or $76.2 \%$ of them are male, while the other $23.8 \%$ are female. Furthermore, the respondents involved in the research were individuals born between 1986-1998, which also gives an idea that they can be categorized as millennial generation and work as a professional.
Hereinafter, this study only uses five alternative investment instruments prioritized by OJK which are deposits, stocks, mutual funds, bonds, and golds. The respondents' choice of the given options could be seen as follows:

TABLE III. INVESTMENT CHOICE OF RESPONDENTS

\begin{tabular}{|c|c|c|}
\hline Deskripsi & $\begin{array}{c}\text { Total } \\
\text { (Respondent) }\end{array}$ & $\begin{array}{c}\text { Total } \\
(\%)\end{array}$ \\
\hline Deposits & 78 & $36 \%$ \\
\hline - $\quad$ Stocks & 67 & $31 \%$ \\
\hline - $\quad$ Mutual Funds & 36 & $17 \%$ \\
\hline - $\quad$ Golds & 21 & $10 \%$ \\
\hline - $\quad$ Bonds & 12 & $6 \%$ \\
\hline
\end{tabular}

Source: Author's Primary Data

Based on the survey result on Table III, 36\% of respondents choose to invest in deposits, $31 \%$ of them prefer stocks, and $17 \%$ of respondents opt for mutual funds. Moreover, the number of respondents investing in bonds and golds are $10 \%$ and $6 \%$ respectively.

B. 4.2 Respondents' Level of Financial Knowledge, Attitude, and Behavior
After conducting research through survey, the author tries to measure the level of financial knowledge possessed by respondents. The measurement utilizes calculations by standard deviation with values as the central tendency. Using this method, respondents' financial knowledge level is classified into 5 (five) categories which include poor, fair, average, good, and excellent. The reference formula explained by Azwar [19] will be utilized as below:

Table IV. Reference Formula for Determining Five Categories

\begin{tabular}{|l|c|c|c|c|}
\hline \multirow{2}{*}{ Category } & Reference Formula & \multicolumn{3}{|c|}{ Frequency } \\
\cline { 3 - 5 } & & $\begin{array}{c}\text { Fin. } \\
\text { Knowledge }\end{array}$ & $\begin{array}{c}\text { Fin. } \\
\text { Attitude }\end{array}$ & 27 \\
behavior
\end{tabular}


Referring to the formula used in Table $\boldsymbol{I V}$, we will look at the result and description of financial knowledge, financial attitude, and financial behavior level of respondents. From the calculation, this research found that the majority of 214 respondents taking part in the survey have had sufficient financial knowledge, financial attitude, and financial behavior. However, there are still some of the professional Millennials who have poor financial knowledge, financial attitude, and financial behavior.

\section{HYPOTHESIS TESTING AND DISCUSSION}

As discussed earlier in analyzing the effect of independent variables on the dependent variable, the author uses testing using the Contingency Analysis technique to calculate the Chi-Square $\left(\chi^{2}\right)$ value. In this case, an explanation will be given for each variable to be discussed through a separate sub-discussion.

A. The Influence of Financial Knowledge on Professional Millennials' Investment Choice

The measurement of financial knowledge was conducted by giving 17 questions to respondents. They were asked to answer using a Likert scale, and here is the respondents' answers after categorized:

TABLE V. CROSS TABULATION OF FINANCIAL KNOWLEDGE AND INVESTMENT CHOICE

\begin{tabular}{|c|c|c|c|c|c|c|}
\hline & Deposits & Stocks & $\begin{array}{l}\text { Mutual } \\
\text { Funds }\end{array}$ & Golds & Bonds & $\begin{array}{l}\text { Total } \\
\text { (Row) }\end{array}$ \\
\hline Poor & 2 & 8 & 3 & 3 & 1 & 17 \\
\hline Fair & 12 & 30 & 9 & 6 & 4 & 61 \\
\hline Average & 19 & 12 & 11 & 3 & 2 & 47 \\
\hline Good & 42 & 16 & 11 & 8 & 4 & 81 \\
\hline Excellent & 3 & 1 & 2 & 1 & 1 & 8 \\
\hline Total Column & 78 & 67 & 36 & 21 & 12 & 214 \\
\hline \multicolumn{3}{|c|}{ Chi-Square Test $(\mathrm{df}=16)$} & \multicolumn{2}{|c|}{ Value } & \multicolumn{2}{|c|}{ Significance } \\
\hline \multicolumn{3}{|c|}{ Pearson Chi-Square } & \multicolumn{2}{|c|}{$30.339 *$} & \multicolumn{2}{|c|}{$0.016^{*}$} \\
\hline \multicolumn{3}{|c|}{ Likelihood Ratio } & \multicolumn{2}{|c|}{30.989} & \multicolumn{2}{|c|}{0.014} \\
\hline \multicolumn{3}{|c|}{ Linear-by Linear Association } & \multicolumn{2}{|c|}{3.875} & \multicolumn{2}{|c|}{0.049} \\
\hline
\end{tabular}

According to the findings above, the study reveals that the most chosen investment is deposits with 78 respondents recorded. Moreover, it shows that 81 respondents have had good financial knowledge. Furthermore, in testing the hypothesis, the author considers two things-one is comparing Significance value to the Margin Error $(\alpha)$ by $5 \%$, and the other is by looking into the Observed ChiSquare Value compared to the values as listed in the ChiSquare table.

From the data in Table $\boldsymbol{V}$, it is known that the Significance value generated from cross-tabulation is 0.016 , and the value is less than the value of $\alpha$, so the author decided to not reject $\mathrm{Ha}_{1}$. Also, the value of Chi-Square $\left(\chi^{2}\right)$ is 30.333 when compared with the value of Chi-Square distribution table $_{(16 ; 5 \%)}$, which results 26.296 , it is clear that the value of $\chi^{2}$ is greater than the $\chi^{2}$ distribution table which also consequently accepts $\mathrm{Ha}_{1}$.

The result of hypothesis testing parallels with Arlan [20] and Aren [21] in their argument that financial knowledge can help an individual in making alternative financial decisions. Financial knowledge also helps someone in assisting someone in determining their finances, considering that financial knowledge has an influence on one's financial health. In addition, the following are the results of surveys on the effect of financial attitude on investment choices.

TABLE VI. CROSS TABULATION ON FINANCIAL ATTITUDE AND INVESTMENT CHOICE

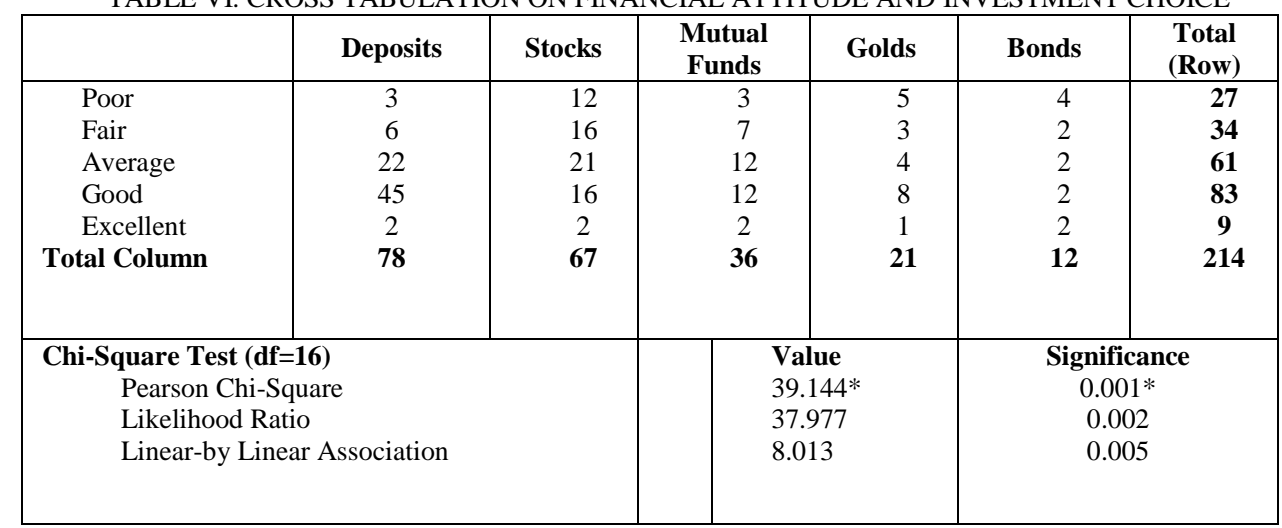

Source: Author's Primary Data

In Table VI, the value of observed Chi-Square $\left(\chi^{2}\right)$ is 39.144. When compared with the value of Chi-Square distribution table ${ }_{(16 ; 5 \%)}$, the result is 26.296. This further shows that the observed $\chi^{2}$ value is greater than the table value, and it also accepts $\mathrm{Ha}_{2}$. Meanwhile, the significance 
value generated from cross-tabulation is 0.001 , and the value is less than the value of $\alpha$, so $\mathrm{Ha}_{2}$ is not rejected.

The testing result claims that financial attitude has a significant effect on investment choices. Likewise, this is similar to the opinion of Herdjiono that states that financial attitude influences the way someone in managing their finances [22]. Financial attitude can also have a positive influence on financial management, including in determining investment instruments that cannot be separated from their respective risk profiles [23].

TABLE VII. CROSS TABULATION OF FINANCIAL BEHAVIOR AND INVESTMENT CHOICE

\begin{tabular}{|c|c|c|c|c|c|c|}
\hline & Deposits & Stocks & $\begin{array}{c}\text { Mutual } \\
\text { Funds }\end{array}$ & Golds & Bonds & $\begin{array}{r}\text { Total } \\
\text { (Row) }\end{array}$ \\
\hline Poor & 4 & 12 & 2 & 4 & 2 & 24 \\
\hline Fair & 2 & 28 & 8 & 3 & 4 & 45 \\
\hline Average & 20 & 7 & 9 & 6 & 1 & 43 \\
\hline Good & 42 & 15 & 12 & 6 & 4 & 79 \\
\hline Excellent & 10 & 5 & 5 & 2 & 1 & 23 \\
\hline Total Column & 78 & 67 & 36 & 21 & 12 & 214 \\
\hline \multicolumn{3}{|c|}{ Chi-Square Test $(\mathrm{df}=16)$} & \multicolumn{2}{|c|}{ Value } & \multicolumn{2}{|c|}{ Significance } \\
\hline \multicolumn{3}{|c|}{ Pearson Chi-Square } & \multicolumn{2}{|c|}{$53.639 *$} & \multicolumn{2}{|c|}{$0.000 *$} \\
\hline \multicolumn{3}{|c|}{ Likelihood Ratio } & \multicolumn{2}{|c|}{59.090} & \multicolumn{2}{|c|}{0.000} \\
\hline \multicolumn{3}{|c|}{ Linear-by Linear Association } & \multicolumn{2}{|c|}{7.090} & \multicolumn{2}{|c|}{0.000} \\
\hline
\end{tabular}

Source: Author's Primary Data

Further, we look at the cross-tabulation results on the effect of financial attitude on investment choices in Table VII. The value of observed Chi-Square $\left(\chi^{2}\right)$ is 53.639, and it is greater than the $\chi_{(16 ; 5 \%)}^{2}$ value in the distribution table, which is 26.296. Accordingly, the author decided to not reject $\mathrm{Ha}_{3}$. Meanwhile, the significance value generated from cross-tabulation is 0.000 and made it valued less than $\square=0,05$. Hence, it can further support the decision to not reject $\mathrm{Ha}_{3}$.

This finding is adjacent to the argument of Grohmann \& Menkoff [18] that notes the level of financial knowledge and financial management habits will contribute to the formation of financial behavior. The better the financial behavior, the bigger possibility that an individual will have an investment with a characteristic that suits the behavior of managing their finances.

\section{CONCLUSION AND FUTURE RECOMMENDATION}

In conclusion, according to the survey and research done in this study, it can be concluded that:

- Financial Knowledge significantly affects the investment choices of professional Millennials. ( $\mathrm{Ha}_{1}$ accepted)

- Financial Attitude significantly affects the investment choices of professional Millennials ( $\mathrm{Ha}_{2}$ accepted)

- Financial behavior significantly affects the investment choices of professional Millennials (Ha $\mathrm{H}_{3}$ accepted)

In doing this research, the author did not get the sampling frame of the target population - the millennial generation who work in professional sector) so that this study is conducted by using non-probability sampling method with purposive sampling type. However, it is still recommended to use probability sampling methods in order to get better research that represents a larger population. In addition, secondary data related to Indonesian financial literacy can only be obtained from the OJK which has a cycle of three years, so researchers are then expected to look for other secondary data sources.

\section{REFERENCES}

[1] Keuangan, O J 2017 Strategi Nasional Literasi Keuangan Indonesia Revisit 2017 Jakarta: OJK

[2] Statistik, B P 2018 Produk Domestik Bruto Indonesia Triwulanan Jakarta: BPS-Statistic Indonesia

[3] Halim A 2015 Analisis Investasi Edisi Kedua Jakarta: Karya Salemba Empat

[4] Meier J, Crocker M 2010 Generation Y in the Workforce: Managerial Challenges the Journal of Human Resource and Adult Learning 6 (1), 68-78

[5] iQuantifi 2017 Millennial Money Mindset Report 2017 Dr Franklin: iQuantifi

[6] Managers P I 2018, Maret Millennials and Investing: What You Need to Know Retrieved Februari 17, 2019, from Prudential Investment Managers: https://www prudential co za/insights/articlesreleases/millennials-and-investing-what-youneed-toknow/

[7] Putri A I 2019 Pengaruh Literasi Keuangan Terhadap Preferensi Pilihan Investasi Generasi Milenial Depok: Skripsi Fakultas Ekonomi dan Bisnis Program Studi Ekstensi Manajemen Universitas Indonesia

[8] Hasibuan B K, Lubis, Y M , and HR, W A 2017 Financial Literacy and Financial Behavior as a Measure of Financial Satisfaction Advances in Economics, Business and Management Research AEBMR, 503-507

[9] Lusardi, Annamaria, and Olivia S M 2014 The Economic Importance of Financial Literacy: Theory and Evidence Journal of Economic Literature, 52 (1): 5-44

[10] Remund D L 2010 Financial Literacy Explicated: The Case for a Clearer Definition in an Increasingly Complex Economy the Journal of Consumer Affairs, 44 2, 276-295

[11] Palameta $C$ N, et al 2016 The link between financial confidence and financial outcomes among working-age Canadians Ottawa: Financial Consumer Agency of Canada

[12] Kurihara Y 2013 Does Financial Skill Promote Economic Growth? International Journal of Humanities and Social Science 3 (8) 92-97

[13] Marsh, Brant A 2006 Examining the Personal Finance Attitudes, Behaviors, And Knowledge Levels of First-Year and Senior Students at BaptistUniversities In the State of Texas Disertasi

[14] OECD 2017, September 22 Five-Generation Workplace, From Baby Boomers to Generation Z. Retrieved Februari 172018 from The Forum Network OECD: https://www.oecd- 
forum.org/users/50593-oecd/posts/20444-five-generationworkplace-from-baby-boomers-to-generation-z

[15] Iklima H 2017 Pengaruh Pengetahuan Keuangan, Sikap Keuangan, Dan Kepribadian Terhadap Perilaku Manajemen Keuangan Pada Pelaku Umkm Sentra Kerajinan Batik Kabupaten Bantul Jurnal Nominal, 7 (1)

[16] Ajzen I 1991 The theory of planned behavior Organizational Behavior and Human Decision Processes, 50: 179-211

[17] Lay A and Furnham A 2018 A New Money Attitudes Questionnaire European Journal of Psychological Assessment 10 $1-10$

[18] Grohmann, Menkoff 2015 Childhood Roots of Financial Literacy Berlin: DIW Berlin

[19] Azwar S 2012 Reliabilitas dan Validitas Yogyakarta: Pustaka Pelajar

[20] Arlan R 2017 Pengaruh Literasi Keuangan dan Profil Risiko Terhadap Variasi Instrumen Investasi yang Dimiliki Pada Generasi Y Depok: Skripsi Fakultas Ekonomi dan Bisanis Program Studi Manajemen Kekhususan Keuangan Universitas Indonesia

[21] Aren S 2016 Pengaruh Literasi Keuangan dan Persepsi Risiko Terhadap Pilihan Investasi Procedia-Social Behavioral Sicences 235

[22] Herdjiono I, Damanik L A 2016 Pengaruh Financial Attitude,Financial Knowledge, Parental Income Terhadap Financial Management Behavior Jurnal Manajemen Teori dan Terapan 9 (3) 226-241

[23] Mien N T N, Thao T P 2015 Factors Affecting Personal Financial Management Behaviors: Evidence from Vietnam Proceedings of the Second Asia-Pacific Conference on Global Business, Economics, Finance and Social Sciences AP15 Vietnam Conference ISBN: 978-1-63415-833-6 10-12 July, 2015 Danang-Vietnam 